\title{
Three dimensional movable books for children
}

\author{
Ali Kılıç ${ }^{1}$ \\ 1 Assoc. Prof. Dr., Fatih Sultan Mehmet Vakıf University, İstanbul, TURKEY, E-mail: mralikilic@gmail.com
}

\begin{abstract}
Three dimensional (3D) "pop-ups" are multisensory books appealing to audio, visual and tactile experiences of readers. They bring children and parents together and positively contribute to the educational and cognitive development of children. The design and production process of pop-ups plays an important role in the efficiency of this contribution. The increasing number and demand towards these books in recent years necessitates an interdisciplinary study from the perspective of visual and media arts, related engineering fields (such as paper engineering) and publishing technologies. Pop-up books are also regarded as educational materials, therefore constituting an interesting subject for pedagogy.
\end{abstract}

Keywords: Child Books, Education, Pop Ups \& Movable, Three-Dimensional, Pedagogy

\section{THREE DIMENSIONAL MOVABLE BOOKS FOR CHILDREN}

It has been widely accepted for a long time that games and toys have great functions both for the education and inner world of children. Playing games has always been a necessary activity for child development. With regard to their own unique inspiration, any object can become part of their games; they play with these objects for many hours and keep living within their own world of dreams. In short, a piece of wood or a pebble can easily turn into a toy for them.

Pedagogues, scientists and artists conduct research for bringing in or devising new toys, variety of games and educational materials for educational purposes that can be utilized by children within the development period so that the requirements arising from modern educational systems can be met. Three dimensional movable books, also known as "pop-up books", is of no exception that they represented one example of leading educational materials that were designed to bring toys and books in conjunction since their emergence in the eighteenth century.

Pop-up books are composed of three dimensional pages and they gain depth when flipping their pages; they have folding mechanisms at the edge of their pages for inducing motion to the characters placed within so that children were assisted to actively participate into the learning process while playing. When they grab 
and begin to turn the pages of these pop-up books, children are enabled in terms of achieving skills and knowledge with their own personal efforts; children find themselves in a substantial three dimensional world which is full of fairies, castles, rabbits, butterflies, giants and the like. They discover varying point of views and experience a special adventure every time they examine the book. In short, by lifting the flaps of the books, pulling, pushing or turning them over, three dimensional pop-up books facilitate children to gain self-confidence and a sense of aesthetics.

The significance of the children's aesthetic and mental development for their families and educators also created a research market for the qualified educational materials. As one form of high-quality educational materials, three dimensional books can make significant and constructive contributions to the child development process by putting parents and the children in tandem with the help of their appeal to the major senses of touching, hearing, and visual orientation. Therefore, the production and design process of three dimensional pop-up books gains further significance due to their vital contribution to the child development and active parental involvement with it.

Current increase in the number of such publications in Turkey calls for an interdisciplinary discussion from the point of pedagogical, visual and communicative art perspectives since they are major training materials on the one hand, and from the respective perspectives of various technologies and engineering branches as these books are commodities of mass production on the other. In the following part, the emergence of three dimensional pop-up books, then production details will be shortly discussed.

\section{HISTORY OF THREE DIMENSIONAL MOVABLE BOOKS}

With the advent of publishing industry, artists, book designers and scientists started to explore ways by which they could add movable pieces to the pages of their works. In the course of time, three dimensional books started to be called as 'pop-ups'1 in a way that draws interests of both children and the collectors. Having movable structures, these books became fascinating items for the readers. In the thirteenth century, Ramon Llull, a mystic and poet from Catalonia2, used a rotating disc to materialize, express and put his thoughts in to practice. In a similar manner, paper discs and volvels3 had been used for astronomic forecasts, fortune-telling and building secret codes and scripts (Aziz, 2002: 24).
Picture 1. Llull, 2003

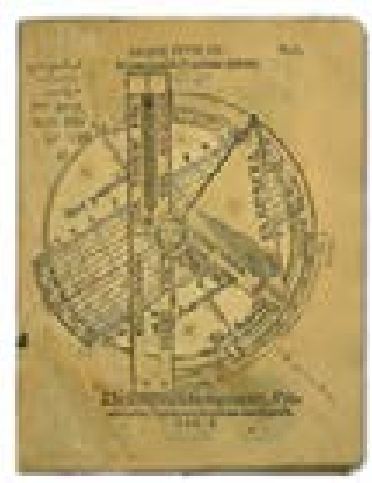

"Flip-books" or "Lift-the-Flap" style books are other types of movable books that were used as early as the fourteenth century. Books of such kind were especially helpful and utilized in the domain of anatomy; various pieces illustrating different sections of the human body were connected at the top and easily placed on the same page. By this technique, innards of human body and internal organs could be taken out in the form of layers and examined easily. This work contains movable parts showing detailed interwoven layers that are illustrative of human body (Pop up and Movable Books, 2008:1).

Picture 2. Vesalius, 2008

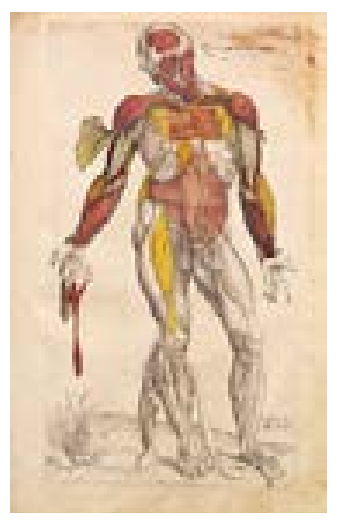

Such type of movable mechanisms and techniques started to be implemented for the books designed for children. Robert Sayer, a book publisher from London, produced 'shape-shifter' books with flaps having hidden figures and with parts that could be easily torn out. Dean \& Son in London became the first publishing house which printed such movable mechanic books in large amounts (Aziz, 2002: 24).

Blue Ribbon Press of New York employed skilled artists and engineers in order to be able to publish series of creative three dimensional books. Most of the amusing characters and themes of these books were directly inspired by popular Walt Disney characters at the time (Pop up and Movable Books, 2008: 2). 
Picture 3. Blue Ribbon Press, 1934

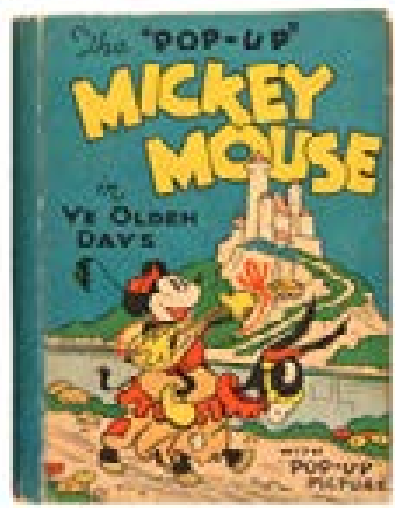

During the nineteenth century, French publishers and toy producers became interested in paper toys and produced well-articulated brand of paper toys including movable books. A. Capendu, a publisher from Paris, published a series of movable books under the title Librarie Enfantine Illustree (Pop up and Movable Books, 2008: 4). Later on, artists from various countries such as S. Louis Giraud from France, Voitech Kubatsa from former Czechoslovakia, Mc Loughlin Brothers from UK, Lothar Meggendorfer from Germany, Raphael Tuch from UK and Julian Wehr again from Germany designed books which had three dimensional figures beginning from late nineteenth century to present day.

Acoustic and audio-visual communication means such as computers obviously brought forth cultural changes. Moreover, these means should be regarded as important as the invention of printing press. Under such circumstances, it would not be incorrect to state that the epoch opened by Guttenberg 4 has come to an end. In the age of new media, the functions and expectations attributed to the books undergo great changes. Issues and strategies pertaining to literacy, or enhancing literary and comprehensive capacity transformed a great extend (Ewers, 1996: 184). It is also crucial, as Ewers emphasized, (1996: 184) that there has been an increase first in terms of devising various efforts to "re-encourage" European people to read, then conduct related field studies.

\section{THREE DIMENSIONAL MOVABLE BOOKS AND CHILDREN}

Today, the activity of producing illustrations for books is accepted as a well-established, sophisticated and respected branch of art and design in advanced countries. Illustration competitions, biennials and symposiums on children books have been organized and new authors and illustrators are introduced to the global literary community in a way underlining the significance of this art for early childhood development (Erkmen, 1998).

The very interaction between the child and the book is significantly facilitated by the addition of the third dimension and movement to the books as well as illustrations. Supplementing books with a third dimension enables them to become more "intimate communication and learning " 5 means as compared to computers, as well as boosting books' multisensory orientation by enhancing active participation with respect to rather "distanced" ordinary books.

Picture 4. Barker, 2007
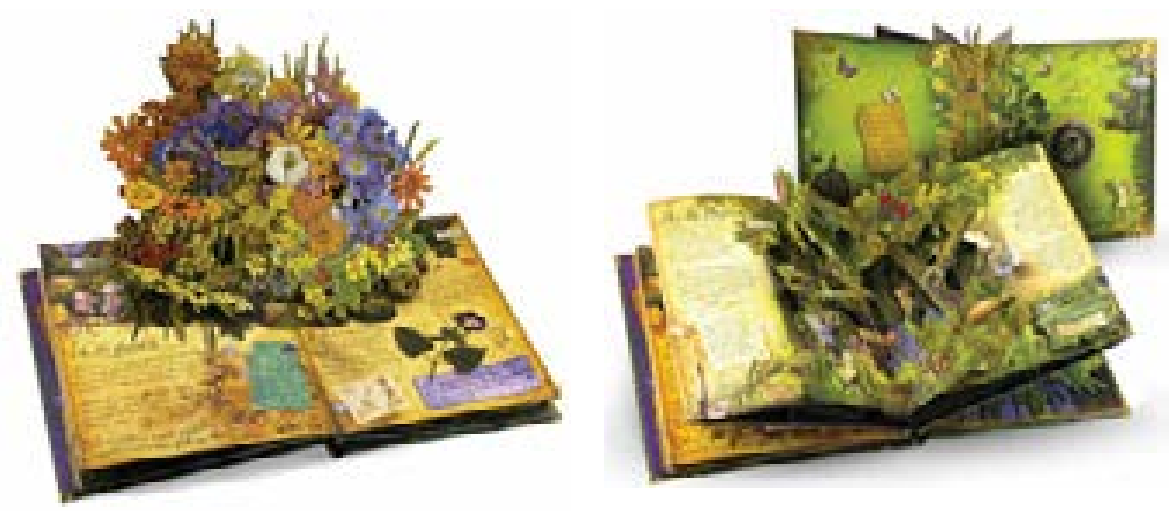
Books have crucial functions with respect to their diverse features for every single stage of childhood development. The books and printed material utilized during the preschool period within which child's linguistic, perceptual motor, social-sensory and cognitive development is rather accelerated, therefore they are crucial in terms of the impact that they provide for the child development as well as preparing the child for the realities of life by improving his/ her audio and comprehensive capabilities (Aral, Gürsoy 2000: 321).

Books for children are the gateways through which humans become acquainted with the art of painting and they constitute the milestones for formal education. A child has his/ her initial education and impressions about plastic arts by means of these books. The most valuable human artifact that children own is the children books together with the toys. Children learn the concepts such as "beautiful", "artificial" and the "ugly" for the first time with the help of these books. Having mentioned children books' importance for early childhood development, it would not be an exaggeration to claim that such a start has a bearing on the rest of child's life. In other words, it is almost impossible to remove these traces which were engraved in child's subconscious in early ages later (Erkmen, 1996: 181).

Picture 5. Casini, 2007

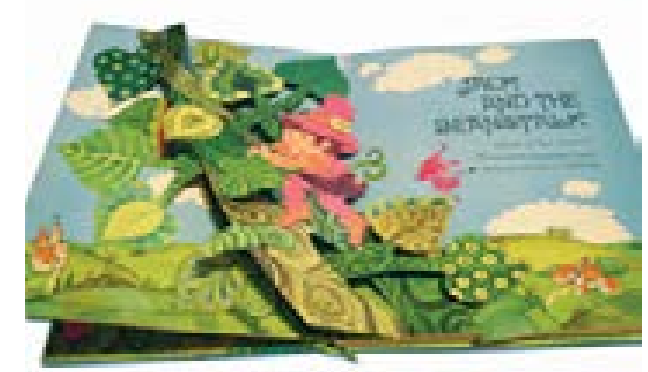

As observed in preschool education in general and kindergartens in particular, books lost their status of being a cultural and pedagogical monopoly recently. Children come across with various means of communication since their birth; in addition to the illustrated fairy-tale books, video-recordings of drama, television shows, and in time computers get into their lives. Therefore, parental assistance becomes a must when children start studying fairy-tale books or illustrated material (Ewers, 1996: 184). As computer games started to replace three dimensional books in early childhood learning, this automatically affected the age of the audience that average reader age decreased from six to ten years to the preschool age in our time (Aziz, 2002: 25).
Picture 6. Spitz, Pollack, 2008

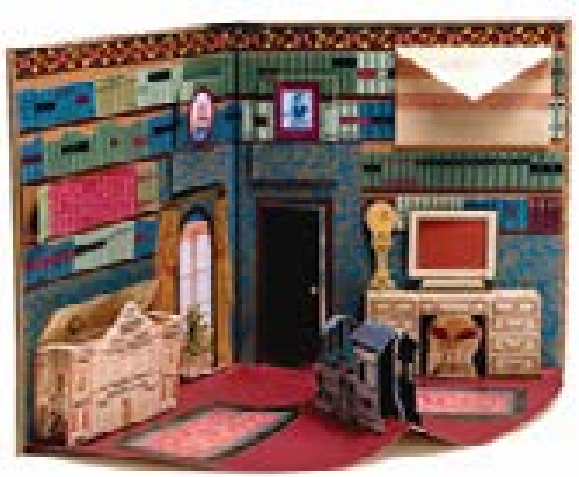

Enhancing a child's creativity is possible with the guidance of a conscious educator. Children become aware of their immediate environment with the help of an educator who can support their motivations, effectively communicate with them and teach them how to observe and experience. By this way, children can also communicate with others easily; moreover, they become able to form their thoughts more creative and personal manner. In short, with the assistance of an effective teacher, children can learn to express their feelings by the medium of arts.

The most important step for the art of communication is the very relation between educator and the child. Assisting the child to internalize his/her own experiences, and become able to make interpretations by conscious and emotion- laden implications is the most important step of communication (Erkmen, 1997).

\section{PRODUCTION PROCESS OF THREE DIMENSIONAL MOVABLE BOOKS}

The production process of three dimensional movable books necessitates an interdisciplinary study from the perspective of different fields such as visual and communication arts, related engineering fields and publishing technologies. Since pop-up books are also regarded as educational materials, they form a subject of interest for pedagogy, too.

While determining the nature of the material as a qualified educational tool to be produced forms the first step of the manufacturing process of three dimensional movable books, the second step necessitates "a team work consisting of an author, a graphic designer and paper engineer" 6 that makes technological and technical structure crucial in creating the material. 
At the production stage of three dimensional pop-up books:

- Paper engineer collects the pieces of illustrations that will be included in the book from different angles. Paper engineer also determines how to place these parts without folding them, or from which points to stick these parts together, how much adhesive should be used, lengths of the drawing strips and the heights of movable parts.

- Then the paper engineer places all of these movable parts on a page and hand in the draft copy to a printing house to be processed.

- By this way, a prototype is prepared to be dissembled and cut into pieces later on.

- Such prototypes are kept arranged till the final product is finalized.

- The final prototype, having cutting marks on it, is sent to the graphic designer who will carry out the drawing stage.

- The final drawing is transferred to the digital environment (i.e., by scanning) and final controls are carried out accordingly. To check if it functions, i.e., folds properly, the pieces are reassembled or put together.

- Scanned pieces are placed on a wide paper or paperboard so that most suitable locations for them within the book form can be determined.

- These digital records in folders are sent for printing. The book is printed using these records.

- Three dimensional pieces are cut either by hand or laser technique. This is the most complicated and critical stage of the preparation process.

- Paper pieces of the printed three dimensional structures are cut one by one with the help of a shearing machine.

- Subsequently, the entire book is completed by affixing three dimensional pieces by hand and placing them on specific pages within the book. (Aziz, 2002: 25)

Picture 7. Carter, 2007

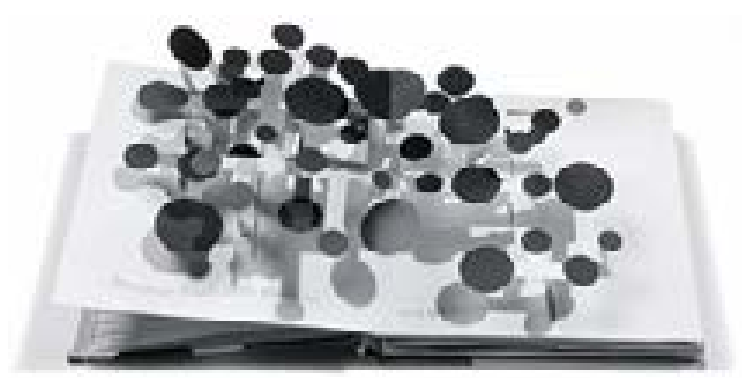

\section{CONCLUSION}

Educational materials are closely related to the scientific, technological and philosophical developments in time. The period started with the Guttenberg's invention of printing press increased the significance of visual educational materials. Within the era following information revolution, the shape and physical properties of educational materials' began to be formed digitally in an ever-increasing manner. In addition to incorporating digital mediums to the educational process, the pop-ups' other crucial function is to critically contribute to the education of preschoolers more than computers and television. The critical contribution arises from the fact that as multisensory educational materials, pop- ups fit the sense of touching, seeing, hearing and three dimensionalperception altogether as well as integrating parents to the learning process in a way that the parental love, affection, and compassion as well as "interpretive" or "hermeneutical" creativity become part of the learning process so that the child's learning becomes ever comprehensive.

Considering the fact that children are crucial for the continuity and persistence of the societies and cultures within which they grow up, the significance of educational materials contributing to their mental, physical and social development becomes much more evident. Consequently, the parental choice regarding a book which constitutes the basic educational material as well as the medium by which parents interact with their kids, gains more prominence since parental guidance on such occasions constitutes the most important step in a child development and socialization.

As a result, within the frame of this study, it is tried to be asserted that three dimensional movable pop-up books for children have great pedagogic role for the child development period. Accordingly, this article also emphasizes that the design, production, marketing and presentation processes of three dimensional movable pop ups need to be tackled from an interdisciplinary perspective which would make room for, such as scientific, educational, sociological, fine arts and engineering approaches. 


\section{REFERENCES}

- ARAL, N. \& GÜRSOY, F. (2000). Kitabın çocuğun gelişiminde yeri ve önemi. 1. Ulusal Çocuk Kitapları Sempozyumu, (pp. 321-333). Ankara, Ankara Üniversitesi Eğitim Bilimleri ve TÖMER Dil Öğretim Merkezi.

- AZIZ, C. (2002). Pop-up magic. Inspire, Summer (11), 24-26. Sweden: Fagerblads Tryckcentra.

- B ARKER, C.MARY ( 2007 ) http://search. barnesandnoble.com/booksearch/isbnInquiry.

- CARTER, D. A. (2007). http://www.nytimes. com/2007/11/11/books/review/Long-t.html.

- CASİNi, F. (2007). http://www.flickr.com/ photos/58766374@N00/562864637

- ERKMEN, N. (1998). Günümüzde Çocuk Kitab1 Resimleme Sanatının Önemi. Bahçelievler Belediyesi 1. Sanat Şenliği Konferansi.

- ERKMEN, N. (1996). Çocuk Kitabi Resimleri. Art Decor 37. 180-186.

- ERKMEN, N. (1997). Çocuk kitabı resimlemesinde çocukla iletişim kurma sanatı. Kadıköy Belediyesi Halk ve Çocuk Kütüphanesi Konferans Dizisi.

- EWERS, H. H. (1996). İlk okuma kitabından çocuk romanına- Almanya' da ilköğretim çağındaki çocuklar için okul dışı okumayı teşvik eden resimli kitaplar, Türkiye ve Almanya'da İlköğretim Ders Kitapları Sempozyumu. 184-187.

- GENOSKO, G. (1999). Mcluhan and Baudrillard. The Master of Implosion, Routledge. London.

- LLULL, R. (2003), http://www.a-website.org/design/ instructional/volvelles.html

- MCLUHAN, M. (2001), Gutenberg Galaksisi, (Çev. Gül Çağalı Güven). Yapı ve Kredi Yayınları, İstanbul.

- Pop up and Movable Books. University of Nort Texas Libraries Web Page. 28 July 2008. from http://www. library.unt.edu/rarebooks/exhibits/popup2/default. $\underline{\mathrm{htm}}$

- SPITZ, L. \& POLLACK, A. J. (2008).http://www. vampandtramp.com/finepress/s/spitz $\% 20 \& \% 20$ pollack.html

- VESALIUS, A. (2008). http://science.kukuchew. com/2008/06/15/andreas-vesalius-anatomicaldrawings/

\section{NOTLAR:}

${ }^{1}$ These books have three dimensional figures which swell when their pages are flipped.
${ }^{2}$ A region in Northern Spain.

${ }^{3}$ Horoscope-like rotating pointers made of paper or paperboard. These were actually discs which had many components and mostly used for astronomic predictions.

4 Marshal McLuhan's study titled Gutenberg's Galaxy (1962) discusses the benefits brought in by the print capitalism or the revolutionary technology of printing press as well as the advantages that would be introduced by electronic revolution with his articulated approach in a significant manner.

${ }^{5}$ See Genosko for the usage of the dichotomy between "intimate" and "distanced" in Mcluhan (1999: 36).

${ }^{6}$ Aziz, 2002: 25. 